\title{
Pedagogy of English Idioms: An Etymological Perspective
}

\author{
Abrar Hussain Qureshi ${ }^{1}$, Behzad Anwar ${ }^{2} \&$ Adnan Tahir ${ }^{3}$ \\ ${ }^{1}$ University of Lahore, Pakpattan, Pakistan \\ ${ }^{2}$ University of Gujrat, Gujrat, Pakistan \\ ${ }^{3}$ Riphah University Faisalbad, Pakistan \\ Correspondence: Abrar Hussain Qureshi, University of Lahore, Pakpattan, Pakistan. E-mail: \\ abrarqureshi74f@gmail.com
}

Received: November 16, 2017 Accepted: December 12, 2017 Online Published: February 10, 2018

doi:10.5539/ijel.v8n3p270 URL: http://doi.org/10.5539/ijel.v8n3p270

\begin{abstract}
In EFL context, there is a considerable shift from single word lexical items to phraseology. Idioms constitute a core part in the phraseology block of the language. Idioms, in spite of their variety and cultural roots, are one of the most neglected areas in EFL perspective. Non-native learners of English as a foreign language do not feel motivated to use idiomatic resources of the language creatively. It is also a fact that pedagogy of idioms to EFL learners has been a challenging task for non-native teachers of the English language. The undertaken research is an effort to establish the utility of the entomological background of idioms in EFL class.
\end{abstract}

Keywords: idioms, EFL learning, etomological handling, better comprehension

\section{Introduction}

Gibbs (1980) is of the opinion that idioms are such kind of frozen pattern of language which permits small or no deviation in structure and time and again carries meanings which cannot be figured out from their individual constituents. In the recent years, figurative idioms have attained immense amount of attention, though they were a neglected area previously in EFL classes. This phenomenon has happened by dent of the increasing attentiveness on the part of the learners and the teachers due to the multi dimensionality of English idioms. In this regard, Cooper (1998) asserts the essential role of idioms which they play while learning a foreign language.

Lionatas (2003) says that figurative idioms are not easy for EFL teachers as well as learners in an EFL classroom for the reason that the meanings of several idioms cannot be located keeping in view their grammatical and lexical components. In this regard, that particular thing becomes a cause of impediment in the systematic instruction of idioms in EFL classrooms (Gramely \& Patzold, 2004).

Moon (1998) is of the opinion that it is very decisive to instruct these idioms as the part of a civilization, culture and mirror image of beliefs of a community. In this regard, examining the etymology of idioms is very crucial, in view of the fact that these expressions were coined in a particular time or moment and because of traditional and cultural causes that cannot be determine by simply assessing the component parts of the idiomatic expression itself. As it has been observed and concluded that each sort of idiom has a particular semantic context, so, if the EFL teachers try to elucidate and convey this semantic context to students in EFL classroom, they possibly will be capable to correlate these idiomatic expressions with the figurative meaning and as a result, they will attain the proficiency to deduce the idioms' meanings from the presented context. There are many factors as political, cultural, and linguistic which cause semantic variation in each idiom. While undertaking pedagogy of English idioms, it's the duty of the teachers to make students realize the value of learning idioms. Once they may be acquainted with the cultural associations and historical co-relation of the idioms along with their etymological perspectives, there will be more chances for better comprehension of EFL idioms successfully.

Idiomatic expression as being a lexical feature of colloquial speech is one of the challenging tasks in EFL context (Bobrow \& Bell, 1973). This critical situation creates hindrance for EFL learners in comprehending English language (Samani \& Hashemian, 2012).

One of the most controversial and complicated areas in L2 teaching in EFL classroom is pedagogy of figurative language in general and idioms in particular. The undertaken research is an attempt to handle the challenging task of EFL idioms in their etymological perspective. After the EFL learners have been made familiar with the 
cultural background of the idioms, it will help them to use linguistic resources of the language successfully. At the same time, as it gives the impression that it is a big and significant challenge from a cultural perspective and subsequently from a pedagogical point of view. The undertaken study has been designed to make students familiar with the etymological perspective of idioms and social background so that learners will be able to use EFL idioms successfully.

\subsection{Statement of the Problem}

EFL learners come across many problems and impediments regarding comprehension of idioms. This phenomenon hampers their speaking, reading, writing and listening comprehensions. This qualitative and descriptive research is an effort to enlighten the EFL teachers about these problems and make an attempt to improve the pedagogy of idiomatic expressions from etymological perspective so that this issue may be resolved effectively.

\subsection{Objectives of the Study}

One of the basic functions of using language is to communicate someone's desires, emotions, feelings, thoughts and ideas to other people. Idioms are the best tool to fulfill all these linguistic needs. The main objectives of the undertaken research are following:

1). The EFL learners will be able to infer the meanings of idiomatic expressions from the etymology.

2). With the help of idiomatic expressions, their four basic skills listening, speaking, reading and writing will be improved.

3). The EFL learners will be able to use idioms effectively and creatively having in view the etymological perspectives of EFL idiomatic expressions.

\section{Literature Review}

Pedagogy of idioms has been a potential area for researchers over the decades since the world has shaped into a global village and the need for cross cultural communication has also increased manifold. While handling the pedagogy of EFL idioms, Clarke \& Nation's (1980) guessing strategy training method includes the following five steps:

$>$ Step 1: Make a decision having in view the unfamiliar words of speech,

$>$ Step 2: Glance instantly at the contextual words,

$>$ Step 3: Look at the vast context of the word,

$>$ Step 4: Presume(guessing)

$>$ Step 5: Verify the guessing.

It may be more difficult for the learner to smudge in the initial position that they have come across an unfamiliar idiom at all. Idioms have more inner construction than the majority of sole words which can be used to guess with context cues. Hence, it would be appealing to observe how successful idiom recognition is and how are they dissimilar from individual words.

\subsection{Teach English Idioms with Dialogue Writing and Role-Play}

Dialogues can supply situations for idiomatic expressions for EFL learners to put into practice general discussion and present students more than enough practice with fundamental speaking skills in context. Firstly, dialogues about idiomatic expressions can be viewed as small plays for students to put into action rather than merely read them audibly. A dialogue is a useful manner of verbal practice for a mixture of ages and levels. Role-plays are also outstanding activities for learners' verbal communication in the comparatively secure environment of the classroom before they must perform consequently in an actual atmosphere. Therefore, dialogues, loaded with idiomatic expressions, present students opportunities to take action and practice verbal skill before encountering the actual world.

\subsection{Applying English Idioms Through Dialogue Writing and Role-play}

Dialogues and role-plays are helpful in black and white and verbal activities. Consequently, learners may be assigned in pairs to write down one dialogue by means of the English idioms presented in EFL classroom. Subsequently, they put the dialogue in action in the subsequent class. Dialogue writing could stimulate students to use idioms in writing devoid of burden. Pair teamwork and role-play activity could facilitate them to bear in mind the dialogue they write during repetitive practices. It is easier and enjoyable for them to memorize English idioms for the reason that they share and enjoy learning English idioms in the company of their friends. Thus, 
dialogue scripting and role-play are constructive and appealing activities for students having an important effect and proficient drills.

Moon (1998) deals with idioms and unchanging expressions and defines idioms as frozen patterns of language which permit slight or no dissimilarity in form, and in the case of idioms, frequently carries meanings which cannot be deducted from their individual ingredients and components:

$>$ Change the order of the words

$>$ Delete a word from it

$>$ Add a word to it

$>$ Replace a word with another;

All the previous efforts have been partially successful in the sense that the EFL learners have not been able to use idioms creatively. The present research is another effort in this regard to motivate the learners to use linguistic resources at full.

\section{Research Methodology}

With the dawn of technology, a new approach in applied linguistics has been emerged. Quantitative approach and other statistical tools have replaced the conventional qualitative methods of research. To undertake the present research, both quantitative and statistical tools have been used. To start with, a pre-test was conducted to determine the idiomatic proficiency of the fifty EFL learners at college level. In the pre-test it was found that most of the EFL learners were at a loss to comprehend and use idioms creatively. After the pre-test results, the EFL learners were motivated to understand the cultural roots of those idioms for a fixed time of thirty days in their EFL class. After thirty days, a post test was conducted to check the impact of the etymologically presented idioms. Finally, the results of the both tests were analysed and elaborated by SPSS.

The undertaken research will follow the parameters, propounded by Leech (1974) to handle idiomatic issues. The main focus of this theory is to determine how the condition of a statement can be used by one person to communicate with another or with a society. There are four types of meaning according to this theorist which are used as the main prospect to teach idioms comprehensively. Those four parameters are following:
a) Conceptual Meaning
b) Connotative Meaning
c) Stylistic Meaning
d) Affective Meaning

\section{Data Analysis}

Pre-test and post-test have been used to collect data. Pre-test is a dimension of the learning process, established during the class as a result of comparing what the student knew before. Then, after thirty days of the teaching of idioms with their etymological perspective, a post has been conducted to check the impact of new method of teaching of EFL idioms. For the detailed analysis and difference between the both groups mean score, standard deviation, difference of means, maximum and minimum range have been calculated separately.

Control group $=$ Pre-test score of control group

Experimental group $=$ Pre-test score of experimental group

PT Control group $=$ Post-test score of control group

PT Experimental Gr $=$ Post-test score of experimental group

Table 1. General statistics

\begin{tabular}{|c|c|c|c|c|c|}
\hline & & Control group & Experimental group & PT Control group & PT Experimental group \\
\hline \multirow[t]{2}{*}{$\mathrm{N}$} & Valid & 25 & 25 & 25 & 25 \\
\hline & Missing & 0 & 0 & 0 & 0 \\
\hline Mean & & 10.08 & 12.08 & 11.24 & 9.40 \\
\hline Std. Deviation & & 1.265 & 3.241 & 2.543 & 3.416 \\
\hline Variance & & 4.993 & 4.993 & 13.273 & 6.833 \\
\hline Range & & 7 & 9 & 12 & 9 \\
\hline Minimum & & 6 & 8 & 1 & 6 \\
\hline Maximum & & 14 & 16 & 14 & 13 \\
\hline
\end{tabular}


Table 2. Paired samples statistics

\begin{tabular}{lllll}
\hline & Mean & $\mathrm{N}$ & Std. Deviation & Std. Error Mean \\
\hline Pair 1 Controlled group & 11.40 & 25 & 2.543 & .515 \\
Experimental group & 10.61 & 25 & 3.414 & .731 \\
\hline
\end{tabular}

Table 2 is about pre-test scores for both groups experimental and control group and there are no great differences between both groups' scores. Here mean is 11.40 in control group and 10.61 in experimental group. Standard deviation in control group is 2.543 and in experimental group is 3.414. Standard error mean in both groups is .515 and .731 . Here we can say that there is significant difference between both groups.

Table 3. Paired samples test

\begin{tabular}{|c|c|c|c|c|c|c|c|c|}
\hline & \multicolumn{8}{|c|}{ Paired Differences } \\
\hline & \multirow[b]{2}{*}{ Mean } & \multirow[b]{2}{*}{ Std. Deviation } & \multirow[b]{2}{*}{ Std. Error Mean } & \multicolumn{2}{|c|}{$\begin{array}{l}95 \% \text { Confidence Interval of } \\
\text { the Difference }\end{array}$} & \multirow[b]{2}{*}{$\mathrm{T}$} & \multirow[b]{2}{*}{$\mathrm{df}$} & \multirow[b]{2}{*}{ Sig. (2-tailed) } \\
\hline & & & & Lower & Upper & & & \\
\hline Control group & .159 & 3.299 & .665 & -1.122 & 1.498 & .239 & 24 & .812 \\
\hline
\end{tabular}

Table 3 shows the paired statistics of experimental group and control group. Table value is .239 that is not significant. Difference of mean is .159 while standard deviation is 3.299. Standard error mean is .665. Confidence interval of difference lower is -1.122 and upper is 1.498 while total is .241 and difference is 24 in both control and experimental group. All these values show that there is not a major and significant difference in the acquired scores of both control and experimental groups.

Table 4. Paired samples correlations

\begin{tabular}{lllll}
\hline & $\mathrm{N}$ & Correlation & Sig. \\
\hline Pair 1 & VAR00001 \& VAR00002 & 25 & -.239 & .242 \\
\hline
\end{tabular}

Table 5. Paired samples statistics

\begin{tabular}{llllll}
\hline & Mean & N & Std. Deviation & Std. Error Mean \\
\hline Pair 1 & experimental group & 17.99 & 25 & 3.496 & .699 \\
& control group & 12.01 & 25 & 2.701 & .519 \\
\hline
\end{tabular}

Table 5 shows that experimental group has greater mean score than control group. Total no of students are 25 . Standard deviation in experimental group is 3.496 and in control group is 2.701. Standard error mean in experimental group is .699 and in control group is .519.

Table 6. Paired samples test

\begin{tabular}{|c|c|c|c|c|c|c|c|c|}
\hline & \multicolumn{8}{|c|}{ Paired Differences } \\
\hline & \multirow[b]{2}{*}{ Mean } & \multirow[b]{2}{*}{ Std. Deviation } & \multirow[b]{2}{*}{ Std. Error Mean } & \multicolumn{4}{|c|}{$\begin{array}{l}95 \% \text { Confidence Interval } \\
\text { of the Difference }\end{array}$} & \multirow[b]{2}{*}{ Sig. (2-tailed) } \\
\hline & & & & Lower & Upper & $\mathrm{T}$ & Df & \\
\hline Experimental group & 7.080 & 2.991 & .338 & 6.411 & 7.632 & 24.571 & 23 & .000 \\
\hline
\end{tabular}


Table 6 shows the paired statistics of experimental and control group's performance. Post-test mean is 7.080 and standard deviation is 2.991. Standard error mean is .338 while interval of difference between lower and upper is 6.411 and 7.632. The total is 24.571 and the difference is 23 . It is concluded that in post-test table value is greater and experimental group's score value is higher than control group.

Table 7. Paired samples correlations

\begin{tabular}{lllll}
\hline & & $\mathrm{N}$ & Correlation & Sig. \\
\hline Pair 1 & VAR00001 \& VAR00002 & 25 & .139 & .501 \\
\hline
\end{tabular}

\section{Results and Discussion}

The scheme of the study has been conceived before the start of the research. 50 students were selected for the pre and post-test from a public College for boys Multan (Pakistan). These 50 students were divided into two separate groups namely control group and experimental group. 25 students were named experimental group and 25 students were named control group. These two groups were checked to see the effect of an innovative way of teaching of idioms through SPSS. Examination of the means, standard deviation and $t$ test is mentioned here.

Table 8. Means, standard deviation and t tests for control and experimental groups

\begin{tabular}{llll}
\hline $\begin{array}{l}\text { Groups } \\
\text { Score }\end{array}$ & Control Group & Experimental Group & $\mathrm{T}$ \\
\hline Pre- Test & & & 1.781 \\
Means & 11.30 & 17.58 & \\
SD & 2.504 & 2.547 & .287 \\
Post- Test & & & \\
Mean & 11.30 & 2.435 & \\
SD & 12.24 & 3.653 & \\
\hline
\end{tabular}

As the table shows that $t$ value of pre-test is greater. As far as the post-test is concerned, the situation is different and $t$ values is greater than the table value. The statement that there is clear difference between control and experimental group is accepted from these results and data. It is safe to conclude that the supposition made earlier that healthy incentive increases the students' performance in learning target language, proves correct.

The findings of the research state that EFL idioms presented with etymological background make a lasting impact on the overall comprehension of language. When learners are aware of cultural and etymological background of idioms they will be able to use idiomatic expressions creatively. The result of this study can be of considerable significance for EFL learners in order to furnish their understanding of idioms. This study provides a great potential to use idiomatic expressions regarding English reading, writing, speaking and listening skills.

\section{Conclusion}

The complexity of idioms most likely stems from the fact that idioms are extremely deep-rooted in the civilization of the target language. There are ethics, themes, and stories at the back of idioms and L2 learners do not contain an opportunity to study and interpret them. Idioms are the mirror image of customs, cultural values, particular features, social attitudes and norms of a civilization. The undertaken research will play a key role for EFL learners in an EFL classroom to recognize and comprehend idioms semantically so that their four skills listening, speaking, reading and writing will be improved and they will be able to use linguistic resources creatively. Finally, the research is far from being thorough. Hence, it has the potential to motivate researchers to investigate other dimensions in the pedagogy of English idioms.

\section{References}

Bobrow, S. A., \& Bell, S. M. (1973). On catching on to idiomatic expressions. Memory \& Cognition, 1(3), 343-346. https://doi.org/10.3758/BF03198118

Cooper, T. C. (1998). Teaching Idioms. Foreign Language Annals, 31(2), 255-266. ttps://doi.org/10.1111/j.1944-9720.1998.tb00572.x

Gibbs, R. (1980). Spilling the beans on understanding and memory for idioms in conversation. Memory, and Cognition, 8, 449-456. https://doi.org/10.3758/BF03213418 
Gramely, S., \& Patzold. K. M. (2004). A Survey in modern English. London: Arnold, Print.

Irujo, S. (1986). A piece of cake: Learning and teaching idioms. EFL Journal, 23, 236-237. https://doi.org/10.1093/elt/40.3.236

Leech, G. (1974). Semantics. Great Britain: Hazell Watson \&Viney Ltd.

Lionatas, J. I. (2003). Killing two birds with one stone: Understanding Spanish VP Idioms in and out of context. Hispania, 86(2), 289-301. https://doi.org/10.2307/20062862

Moon, R. (1998). Fixed expressions and idioms in English. A corpus-based approach. Oxford: Clarendon Press.

Palmer, F. R. (1976). Semantics: A new outline. Melbourne: Cambridge University press.

Samani, E. R., \& Hashemian, M. (2012). The effect of conceptual metaphors on learning idioms by 12 learners. International Journal of English Linguistics, 2(1), 249. https://doi.org/10.5539/ijel.v2n1p249

Swinney, D. A., \& Cutler, A. (1979). An access and processing of Idiomatic Expressions. Journal of Verbal Learning and Verbal Behavior, 18, 523-534. https://doi.org/10.1016/S0022-5371(79)90284-6

Watson, J. (1998). Teaching Idioms: Developing awareness of effect and appropriateness. Modern English Teacher, 7(1), 15-19.

\section{Copyrights}

Copyright for this article is retained by the author(s), with first publication rights granted to the journal.

This is an open-access article distributed under the terms and conditions of the Creative Commons Attribution license (http://creativecommons.org/licenses/by/4.0/). 